\title{
ANALISIS KANDUNGAN NITRAT DAN PHOSFAT DI TAMBAK BERBEDA TERHADAP PERTUMBUHAN RUMPUT LAUT (Gracilaria verrucosa (Hudson) Papenfuss) Oleh: Patahiruddin
}

(Program Studi Akuakultur Fakultas Perikanan Universitas Andi Djemma)

\begin{abstract}
ABSTRAK
Pertumbuhan rumput laut membutuhkan nutrient yang akan mempengaruhi pertumbuhannya berupa nitrat dan phosfat. Nitrat adalah bentuk nitrogen utama dalam perairan alami dan merupakan nutrien utama bagi pertumbuhan alga. Nitrogen dibutuhkan oleh tanaman untuk proses fotosintesis. Phosfat merupakan unsur yang esensial bagi tumbuhan dan algae aquatik serta sangat mempengaruhi tingkat produktivitas perairan. Rumput laut (Gracilaria verrucosa) merupakan salah satu jenis alga merah (Rhodophyta) yang banyak dibudidayakan di tambak dan menjadi bahan dasar penghasil agar. Rumput laut ditanam menggunakan metode lepas dasar dengan bobot $150 \mathrm{gram} / \mathrm{m}^{2}$. Penelitian ini bertujuan untuk menganalisa pertumbuhan rumput laut berdasarkan kandungan nitrat dan phosfat di substrat tambak budidaya di wilayah Kecamatan Suli Kabupaten Luwu dan Kecamatan Wara Timur Kota Palopo Sulawesi Selatan. Pengambilan sampel dilakukan di dua lokasi tambak yang berbeda dengan jarak $\pm 75 \mathrm{~km}$. Pengambilan sampel dan pengukuran parameter fisika kimia perairan dilakukan setiap 7 hari. Petak percobaan berupa plot segi empat $2 \mathrm{~m} \times 3 \mathrm{~m}$. Data dianalisis dengan analysis of variance (ANOVA). Hasil penelitian di area Suli dan Wara menunjukkan bahwa laju pertumbuhan biomassa tertinggi terjadi pada kerapatan bibit $150 \mathrm{gr} / \mathrm{m}^{2}$ sebanyak 3,69 \% dan 2,51\% berat kering per hari. Substrat tambak budidaya berupa fosfat memberikan pengaruh nyata terhadap pertumbuhan biomassa rumput laut G.verrucosa.
\end{abstract}

Kata kunci : Pertumbuhan, nitrat, phosfat, Alga merah, metode lepas dasar.

\section{PENDAHULUAN}

Budidaya rumput laut (Gracilaria verrucosa) memiliki peranan penting dalam usaha meningkatkan produksi perikanan guna memenuhi kebutuhan pangan dan gizi serta memenuhi kebutuhan pasar dalam negeri dan luar negeri, memperluas lapangan pekerjaan, meningkatkan pendapatan dan kesejahteraan nelayan dan petani ikan serta menjaga kelestarian sumber hayati perairan (Aslan, 2006). Budidaya G.verrucosa merupakan kegiatan budidaya yang populer karena G.verrucosa mampu beradaptasi terhadap kondisi ekologi di tambak, tingkat produksi yang lebih tinggi, dan kualitas gel yang lebih baik (Doty, 1986)

Tingginya permintaan komoditas rumput laut untuk kebutuhan industri di dalam dan luar negeri harus diimbangi dengan upaya penyediaan bahan baku yang berkualitas dan berkesinambungan (Kadi, 2004). Produksi G.verrucosa dari tambak dapat mencapai minimal satu ton kering/ha/periode tanam (4-6 minggu) (Alamsjah dkk., 2010). Salah satu kendala utama dalam pencapaian jumlah produksi adalah kondisi nutrient substrat dan nutrient perairan tambak. Oleh karena itu diperlukan suatu penelitian terkait dengan faktor-faktor yang mempengaruhi pertumbuhan. Pertumbuhan G.verrucosa dipengaruhi oleh dua faktor yaitu faktor internal dan 
faktor eksternal. Faktor internal yang berpengaruh antara lain jenis, galur, thallus (bibit) dan umur. Sedangkan faktor eksternal yang berpengaruh antara lain lingkungan, jarak tanam dan teknik penanaman (Kamlasi, 2008).

Penelitian ini, ingin mengkaji faktor-faktor lingkungan yang mempengaruhi pertumbuhan G.verrucosa. Salah satu faktor lingkungan yang banyak memberikan berpengaruh dalam kegiatan budidaya budidaya G.verrucosa yaitu nitrat dan phosfat. Menurut Tambaru dan Samawi (1996), kebutuhan nitrat oleh setiap alga sangat beragam. Apabila kadar nitrat dibawah 0,1 atau diatas $45 \mathrm{mg} / \mathrm{l}$, maka nitrat merupakan faktor pembatas berarti pada kadar demikian nitrat bersifat toksik. Menurut Effendi (2003), phosfat merupakan unsur yang esensial bagi tumbuhan dan alga aquatik serta sangat mempengaruhi tingkat produktivitas perairan. Dengan melakukan analisis nitrat dan phosfat di substrat dan perairan tambak budidaya diharapkan akan didapatkan jumlah kandungan nitrat dan phosfat yang sesuai untuk memberikan pertumbuhan G.verrucosa yang lebih baik pada masing-masing area budidaya. Dengan demikian, kualitas yang baik dan produksi yang maksimal dapat dicapai dalam upaya memenuhi kebutuhan pasar dan peningkatan pendapatan petani yang pada akhirnya ketahanan pangan juga akan terjaga dengan baik.

\section{METODE PENELITIAN}

Penelitian dilaksanakan selama 40 hari di Kecamatan Suli Kabupaten Luwu dan Kecamatan Wara Timur Kota Palopo Provensi Sulawesi Selatan. Jarak antara 2 (dua) area penelitian $75 \mathrm{~km}$. Pemilihan lokasi tersebut atas pertimbangan keduanya dianggap sudah representatif untuk mewakili area budidaya G. verrucosa. Bahan yang digunakan dalam penelitian ini yaitu bibit $G$. verrucosa dari tambak budidaya sekitar lokasi penelitian dan sampel substrat tanah dan air tambak budidaya yang diambil di dua lokasi penelitian.

Data yang digunakan dalam penelitian ini terdiri dari dua jenis, yaitu data primer dan sekunder. Data primer diperoleh langsung dari sampel yang diambil di area budidaya G. verrucosa. Sementara data sekunder akan diperoleh dari studi literatur dan data-data yang berasal dari instansi-instansi terkait seperti Badan Lingkungan Hidup Kabupaten Luwu dan Kota Palopo dan Dinas Perikanan Kabupaten Luwu dan Kota Palopo.

Parameter yang diukur, yaitu: berat biomassa basah G.verrucosa, kandungan nitrat dan phosfat tanah dan air tambak. Pengukuran parameter variable pendukung berupa salinitas, kecerahan air, suhu, $\mathrm{pH}$ air, dan oksigen terlarut (DO) di lakukan langsung di lokasi penelitian. Sedangkan untuk parameter nitrat dan phosfat diukur di Laboratorium Hara Tanah Maros Sulawesi-Selatan. Laju pertumbuhan mutlak Gracilaria verrucosa dapat diperoleh dari hasil pengurangan berat tanaman uji pada akhir penelitian dengan berat awal pemeliharaan dengan menggunakan rumus pertumbuhan mutlak (Everhart, Eipper dan Youngs, 1975 dalam Effendie, 2000) yaitu:

Keterangan :

$$
\mathbf{H}=\mathbf{W} \mathbf{t}_{\mathbf{1}}-\mathbf{W} \mathbf{t}_{\mathbf{0}}
$$

$\mathrm{H}$ : Pertumbuhan mutlak Gracilaria verrucosa (gram)

$\mathrm{Wt}_{1}$ : Berat Gracilaria verrucosa akhir penelitian (gram)

$\mathrm{Wt}_{0}$ : Berat Gracilaria verrucosa awal penelitian (gram)

Laju pertumbuhan harian Gracilaria verrucosa uji, dihitung berdasarkan metode Jauncey dan Rose (1982 dalam Masjuni, 2007) : 
keterangan:

$$
S G R=\frac{\ln W t 1-\ln W t 2}{t 1-t 2} X 100 \%
$$

SGR: laju pertumbuhan harian tanaman uji (\%)

$\mathrm{Wt}_{1}$ : berat tanaman uji pada akhir pemeliharaan (gr)

$\mathrm{Wt}_{2}$ : berat tanaman uji pada awal pemeliharaan (gr)

$\mathrm{t}_{1}, \mathrm{t}_{2}:$ waktu (hari)

Rancangan percobaan yang akan digunakan ialah Rancangan Acak Kelompok (RAK). Respon kandungan nitrat dan phosfat terhadap laju pertumbuhan dianalisis dengan analysis of variance (ANOVA). Hasil analisis disajikan dalam bentuk gambar.

\section{HASIL DAN PEMBAHASAN}

Penelitian pertumbuhan rumput laut (Gracilaria verrucosa) dengan kerapatan bibit (biomassa basah), yaitu: $150 \mathrm{gr} / \mathrm{m}^{2}, 250 \mathrm{gr} / \mathrm{m}^{2}$ dan $350 \mathrm{gr} / \mathrm{m}^{2}$ pada tambak budidaya di Kecamatan Suli Kabupaten Luwu dan Kecamatan Wara Timur Kota Palopo selama 40 hari dengan empat kali pengamatan. Hasil anova perlakuan kerapatan bibit terhadap pertumbuhan biomassa G.verrucosa di di area Suli menunjukkan hubungan yang nyata pada taraf 5\% (sig.0,016). Signifikan jika nilai p< 0,05 (Ghomez dan Ghomez, 2010). Berikut disajikan data laju pertumbuhan G.verrucosa area Suli.

Tabel 1. Data hasil pengukuran bobot kering Gracilaria verrucosa area A

\begin{tabular}{cccc}
\hline $150 \mathrm{gr} / \mathrm{m}^{2}$ & Ulangan 1 & Ulangan 2 & Ulangan 3 \\
\hline 0 & 10,91 & 10,25 & 10,13 \\
13 & 15,148 & 15,12 & 16,31 \\
26 & 21,81 & 21,23 & 20,91 \\
39 & 25,91 & 26,21 & 26,01 \\
\hline $250 \mathrm{gr} / \mathrm{m}^{2}$ & Ulangan 1 & Ulangan 2 & Ulangan 3 \\
\hline 0 & 16,30 & 17,62 & 16,01 \\
13 & 22,75 & 22,11 & 22,40 \\
26 & 24,31 & 25,13 & 24,95 \\
39 & 32,31 & 31,69 & 30,98 \\
\hline $350 \mathrm{gr} / \mathrm{m}^{2}$ & Ulangan 1 & Ulangan 2 & Ulangan 3 \\
\hline 0 & 25,67 & 24,06 & 24,22 \\
13 & 27,81 & 28,71 & 27,52 \\
26 & 30,11 & 30,88 & 31,57 \\
39 & 33,19 & 32,87 & 33,54 \\
\hline
\end{tabular}

Hasil pengamatan laju pertumbuhan G.verrucosa di area suli menunjukkan bahwa laju pertumbuhan terendah pada area suli terjadi pada pengamatan pertama hari ke-10 pada kerapatan bibit $150 \mathrm{gr} / \mathrm{m}^{2}$. Rendahnya laju pertumbuhan G.verrucosa pada awal pengamatan, disebabkan oleh adanya proses adaptasi G.verrucosa terhadap kondisi lingkungan tambak budidaya. Faktor lingkungan merupakan salah satu faktor yang mempengaruhi kehidupan rumput laut, yaitu: kondisi substrat perairan, metode budidaya, suhu, arus, salinitas, kecerahan, penyediaan bibit, penanaman bibit, perawatan selama pemeliharaan, hama dan penyakit (Anggadiredja dkk., 2006). 
Laju pertumbuhan dengan kerapatan bibit $350 \mathrm{gr} / \mathrm{m}^{2}$ pada pengamatan pertama hari ke-10 justru menujukkan hasil yang berbeda dengan kerapatan $150 \mathrm{gr} / \mathrm{m}^{2}$. Hal ini menunjukkan bahwa pada densitas yang rendah, yield/biomassa tergantung pada cacah individu, tetapi ketika tumbuhan cukup rapat untuk saling berpengaruh, maka biomassa dapat diprediksi tanpa tergantung kerapatannya (Kira et al., 1953).

Laju pertumbuhan tertinggi pada area Suli terjadi pada pengamatan keempat hari ke-40 pada kerapatan bibit $250 \mathrm{gr} / \mathrm{m}^{2}$. Tingginya laju pertumbuhan pada pengamatan keempat disebabkan G.verrucosa telah mencapai umur dewasa. Pada komunitas dewasa, populasi tidak tergantung pada kerapatan bibit pada beberapa kisaran densitas. Jadi perbedaan densitas terkompesasikan oleh ukuran individu. Semakin populasi berkembang, maka pertumbuhan sangat tergantung pada kerapatan populasi, karena hal tersebut akan berpengaruh pada laju sintasan dan reproduksi (Shinozaki and Kira, 1956). Brower et al (1990) menjelaskan bahwa populasi baik hewan maupun tumbuhan proporsi individu yang muda dan tua selalu berubah dalam unit waktu tertentu. Kerapatan biomassa mencapai maksimum ketika biomassa rumput laut sama dengan carrying capacity, sehingga pada saat itu rumput laut Gacilaria tidak lagi melakukan pertumbuhan (Kartono dkk., 2008). Selain itu, Variasi ukuran populasi yang berbeda dalam suatu ekosistem pada usia yang sama merupakan hasil dari perbedaan genetik ditingkat pertumbuhan atau perbedaan waktu munculnya benih (tunas) (Weiner dan Thomas, 1986).

Hasil anova perlakuan kerapatan bibit terhadap pertumbuhan biomassa G.verrucosa verrucosadi di area Wara menunjukkan hubungan yang tidak nyata pada taraf 5\% (sig.0,086). Signifikan jika nilai p< 0,05 (Ghomez dan Ghomez, 2010). Berikut data pertumbuhan biomassa kering G.verrucosa di area Wara.

Tabel 2. Data hasil pengukuran bobot kering Gracilaria verrucosa area Wara

\begin{tabular}{cccc}
\hline $150 \mathrm{gr} / \mathrm{m}^{2}$ & Ulangan 1 & Ulangan 2 & Ulangan 3 \\
\hline 0 & 12,40 & 11,64 & 11,82 \\
13 & 13,52 & 14,01 & 12,87 \\
26 & 15,21 & 14,92 & 15,06 \\
39 & 16,21 & 13,71 & 13,93 \\
\hline $250 \mathrm{gr} / \mathrm{m}^{2}$ & Ulangan 1 & Ulangan 2 & Ulangan 3 \\
\hline 0 & 17,84 & 19,13 & 18,35 \\
13 & 18,61 & 18,37 & 18,52 \\
26 & 20,90 & 21,33 & 20,72 \\
39 & 18,58 & 22,01 & 20,94 \\
\hline $350 \mathrm{gr} / \mathrm{m}^{2}$ & Ulangan 1 & Ulangan 2 & Ulangan 3 \\
\hline 0 & 23,75 & 22,87 & 22,85 \\
13 & 23,93 & 23,16 & 24,11 \\
26 & 25,59 & 25,80 & 26,01 \\
39 & 22,37 & 20,22 & 20,26 \\
\hline
\end{tabular}

Menunjukkan laju pertumbuhan terendah pada area Wara terjadi pada pengamatan keempat hari ke-40 pada kerapatan bibit $350 \mathrm{gr} / \mathrm{m}^{2}$. Rendahnya laju pertumbuhan pada pengamatan hari ke-40 disebabkan rendahnya $\mathrm{pH}$ pada substrat. Menurut Soesono (1989) dalam Alifatri (2012), pengaruh $\mathrm{pH}$ bagi pertumbuhan G.verrucosa sangat besar dan penting karena kisaran $\mathrm{pH}$ yang kurang dari 6,5 akan 
menekan laju pertumbuhan bahkan tingkat keasamannya dapat mematikan dan tidak ada laju reproduksi.

Laju pertumbuhan tertinggi pada area Wara berbanding terbalik dengan laju pertumbuhan di area Suli. Laju pertumbuhan tertinggi justru terjadi pada awal pengamatan pertama hari ke-10. Pertumbuhan tertinggi terjadi pada kerapatan bibit $250 \mathrm{gr} / \mathrm{m}^{2}$. Kuat dugaan bahwa laju pertumbuhan G.verrucosa pada awal musim tanam cukup tinggi karena G.verrucosa menyerap nutrien berupa fosfat dan nitrat cukup tinggi. Hasil penelitian Gordillo et al. (2002) menunjukkan bahwa laju penyerapan fosfat dan nirat sesuai dan memiliki korelasi positif dengan peningkatan laju pertumbuhan. Menurut Buschmann et al. (2004); Martines and Rico (2004), pertumbuhan dan biomassa dapat tercapai dengan baik bila rumput laut tercukupi oleh kedua unsur tersebut. Ketersedian fosfat dan nitrat di perairan seringkali menjadi faktor pembatas (Buschmann et al., 2004; Martines and Rico, 2004). Tidak terdeteksinya kandungan fosfat air di area penelitian tidak menyebabkan fosfat sebagai faktor pembatas pertumbuhan karena fosfat diserap dari substrat tambak.

Nitrogen di perairan berupa nitrogen anorganik dan organik. Nitrogen anorganik terdiri dari ammonia $\left(\mathrm{NH}_{3}\right)$, ammonium $\left(\mathrm{NH}_{4}\right)$, nitrat $\left(\mathrm{NO}_{3}\right)$, dan molekul nitrogen $\left(\mathrm{N}_{2}\right)$ dalam bentuk gas. Nitrogen organik berupa: protein, asam amino, dan urea. Bentuk-bentuk ini kemudian mengalami transformasi di perairan sebagai bagian dari siklus nitrogen (Efendi, 2003). Hasil pengukuran kadar nitrat air di area Suli, yaitu 0,079-0,115 ppm dan kadar nitrat di area Wara, yaitu 0,073-0,087 ppm. Konsentrasi nitrat air yang diperoleh selama penelitian di area Suli dan area Wara cukup stabil tetapi konsentrasinya lebih rendah bila di bandingkan dengan pernyataan Andarias (1992), kisaran nitrat yang layak untuk pertumbuhan rumput laut adalah 0,9-3,5 ppm. Konsentrasi nitrat air yang rendah ternyata tidak memberikan pengaruh negatif terhadap pertumbuhan G.verrucosa diarea penelitian.

Nitrat merupakan salah satu unsur yang dibutuhkan untuk pertumbuhan dan G.verrucosa sangat sensitif terhadap konsentrasi nitrogen yang rendah (Edelstein et al.,1976 in BOBP, 1989). Menurut Simanjutak (2006), kandungan nitrogen yang tinggi disuatu perairan dapat disebabkan oleh limbah yang berasal dari domestik, pertanian, peternakan dan industri. Hasil pengukuran kadar nitrat substrat di area A, yaitu 2,744-2,895 mg/l dan di area B, yaitu 2,179-2,504 mg/l. Konsentrasi tersebut layak untuk melakukan kegiatan budidaya bila dilihat dari pernyataan Tambaru dan Samawi (1996), nitrat sebagai faktor pembatas jika konsentrasinya $<0,1 \mathrm{ppm}$ dan $>$ 4,5 ppm.

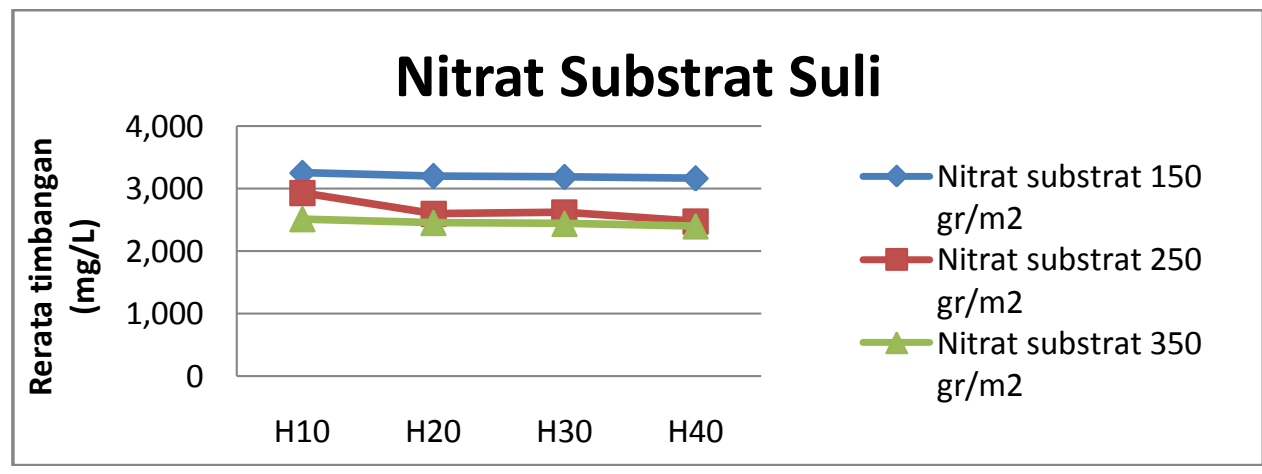




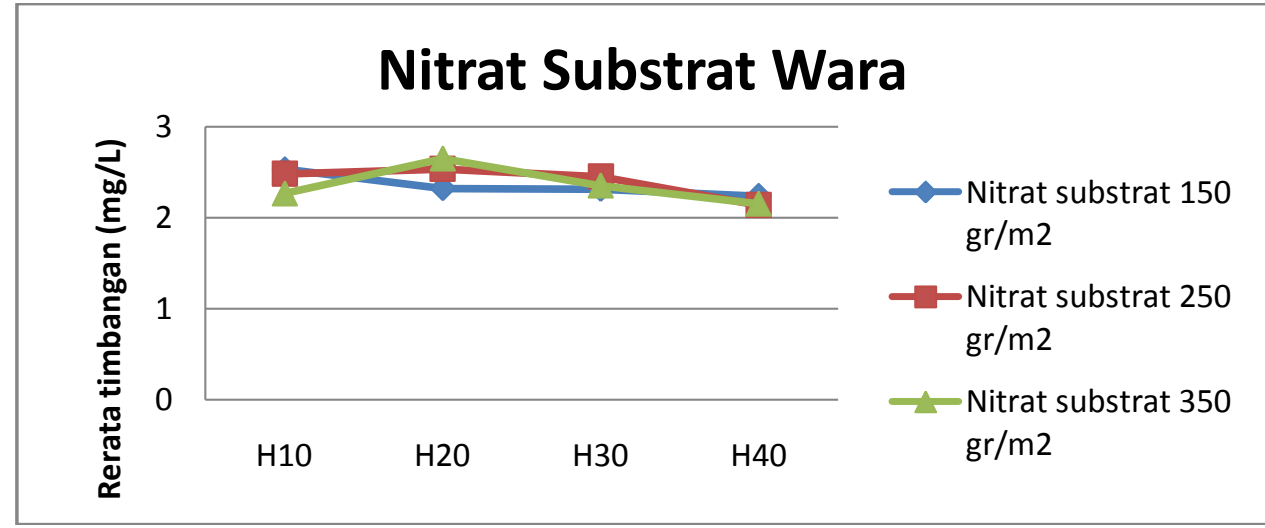

Nitrogen dapat meningkatkan pertumbuhan dan produksi budidaya rumput laut. Hasil penelitian Buschmann et al. (2004) menunjukkan bahwa beberapa alga merah, seperti Gracilaria tumbuh lebih baik pada kondisi ammonium yang tinggi, sedangkan pada jenis lain, seperti Chondrus crispus dan Soliera chordalis, terlihat lebih baik ketika dilakukan penambahan nitrat, Namun dalam hal penyerapan nitrat, beberapa jenis algae memiliki perbedaan dalam menyerap unsur $\mathrm{N}$, dimana ada jenis alga yang cenderung lebih dahulu menggunakan nitrat dan adapula yang lebih dahulu menggunakan ammonium (Roymont, 1980 dalam Patadjai, 2007).

Secara visual dasar perairan (tambak) di lokasi penelitian memiliki jenis substrat lumpur berpasir. Substrat tambak yang baik untuk kegiatan budidaya G.verrucosa adalah lumpur berpasir (Trono, 1986) karena merupakan jenis tanah yang tidak mudah menyerap air dan kaya bahan organik (zat hara) sehingga mempercepat pertumbuhan tanaman (Alifatri, 2012). Dengan demikian substrat yang ada di lokasi penelitian dapat dikategorikan baik untuk melakukan kegiatan budidaya dan menunjang pertumbuhan G.verrucosa (Zatnika, 2009 dalam Alifatri, 2012). Penambahan pupuk $\mathrm{N}$ yang banyak dengan anggapan akan meningkatkan hasil produktivitas tanaman merupakan suatu hal yang salah sebab pada kenyataannya pemberian pupuk $\mathrm{N}$ yang berlebihan akan mengurangi hasil panen dan akan meningkatkan tingkat kehilangan $\mathrm{N}$ dan tingkat efisiensi penggunaan pupuk $\mathrm{N}$ akan menjadi berkurang (Xiang et al., 2008).

Fosfat diperlukan G.verrucosa untuk pertumbuhannya. Pengukuran kandungan fosfat air di lokasi penelitian area A dan area B tidak dapat terdeteksi karena konsentrasinya sangat kecil, hal ini menunjukkan bahwa perairan memiliki tingkat kesuburan rendah sesuai dengan peryataan Joshimura (1983) dalam effendi (2003), perairan dengan tingkat kesuburan rendah jika kadar fosfatnya berkisar $0-0,02 \mathrm{mg} / \mathrm{l}$, tingkat kesuburan tertinggi berkisar 0,021 - 0,05 mg/l. Hasil pengukuran kandungan kadar fosfat tersedia substrat tambak di area Suli, yaitu 20,93-23,81 mg/l dan kadar fosfat tersedia substrat tambak di area Wara, yaitu 17,71-19,23 mg/l. Hasil pengukuran kandungan kadar fosfat total substrat tambak di area Suli, yaitu 29,18$39,57 \mathrm{mg} / \mathrm{l}$ dan kadar fosfat total substrat tambak di area Wara, yaitu 21,46-27,25 $\mathrm{mg} / \mathrm{l}$. Konsentrasi fosfat yang tinggi di substrat tambak ternyata menjadi penyuplai kebutuhan fosfat untuk pertumbuhan G.verrucosa, hal tersebut terlihat dari menurunya tingkat kadar fosfat substrat setiap pengamatan. Andarias (1992) menyatakan bahwa kisaran fosfat yang baik untuk pertumbuhan rumput laut adalah 0,09-1,80 mg/l. Batas terendah konsentrasi fosfat untuk pertumbuhan optimun alga 
berkisar antara 0,018-0,09 ppm dan batas tertinggi berkisar antara 8,90-17,8 ppm apabila nitrogen dalam bentuk nitrat, bila nitrogen dalam bentuk ammonium batas tertinggi berkisar pada 1,78 ppm. Rumput laut memiliki efisiensi penyerapan N $32 \%$ dan P 19\% (Chandrkrachang et al., 1991).
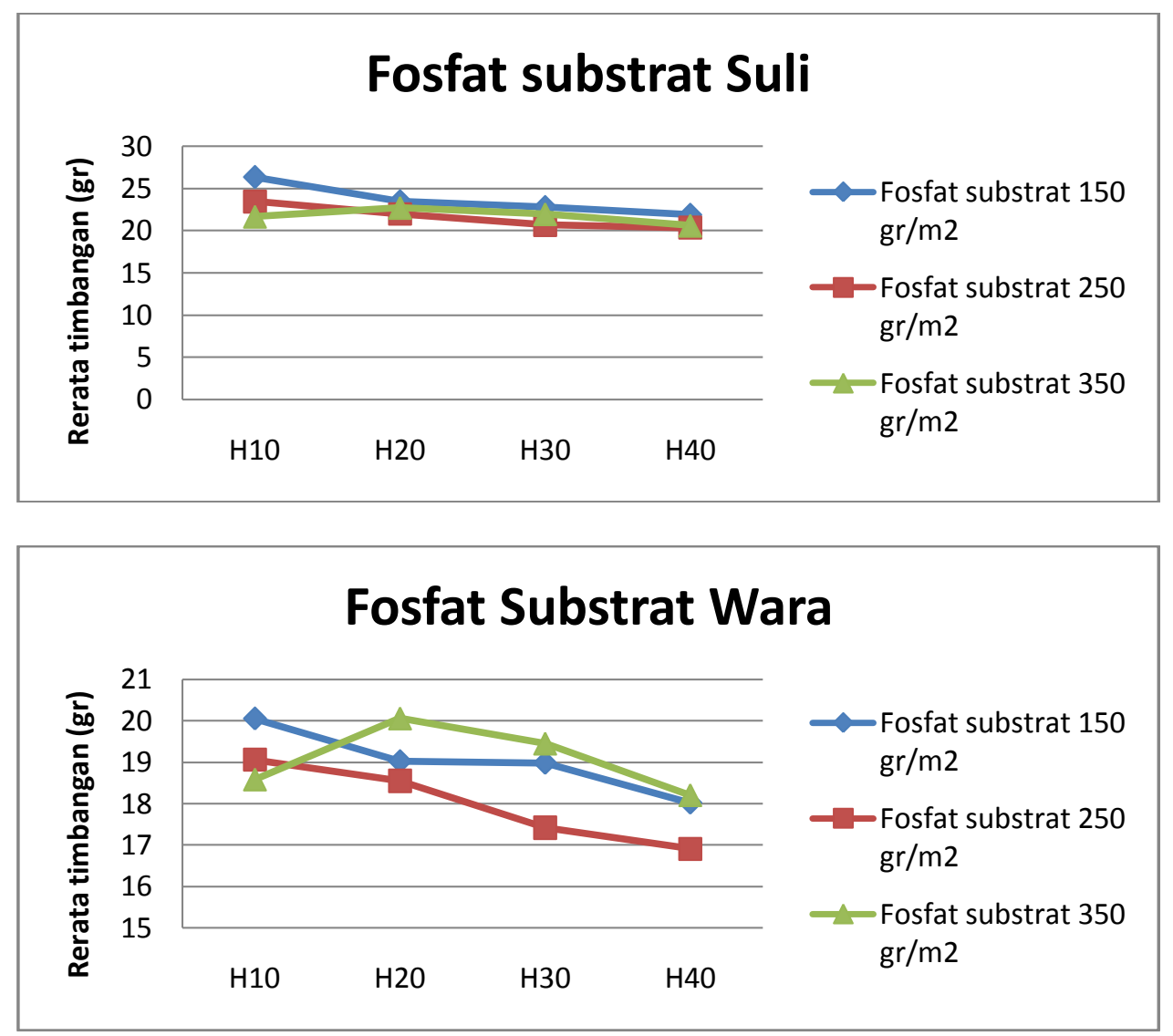

Kebutuhan fosfat untuk pertumbuhan optimum bagi alga dipengaruhi oleh bentuk senyawa nitrogen. Schindler dalam Reynolds (1993) menjelaskan bahwa biomassa fitoplankton (algae) maksimum dibeberapa danau di daerah empat musim dibatasi mutlak oleh persediaan fosfat, sedangkan di laut fitoplankton dibatasi oleh persediaan nitrogen. Batas tertinggi konsentrasi fosfat akan lebih rendah jika nitrogen berada dalam bentuk garam ammonium dan sebaliknya jika nitrogen dalam bentuk nitrat, konsentrasi tertinggi fosfat yang diperlukan akan lebih tinggi (Andarian, 1991 dalam Patadjai, 2007).

Faktor lingkungan merupakan salah satu faktor yang mempengaruhi kehidupan rumput laut sedangkan informasi mengenai laju penyerapan nutrien tidak hanya penting sebagai faktor dari produktivitas rumput laut tetapi juga dapat digunakan untuk melakukan penentuan kelayakan lahan, estimasi luas hamparan budidaya rumput laut dan upaya meminimalkan beban limbah nutrien dari lingkungan sebagaimana dalam Ask dan Azanza (2002) mengatakan bahwa peningkatan petunjuk untuk seleksi lokasi dan penelitian-penelitian tentang penyerapan nutrien dapat menggambarkan potensi lahan sebagai sumber nutrien yang bermanfaat bagi suatu komunitas dan sistem budidaya disekitarnya. 
Konsentrasi dan laju penyediaan nitrat memiliki hubungan yang erat dengan kondisi tanah dan pengelolaannya yang berada di sekitar perairan tersebut karena nitrat dapat dengan mudah melewati lapisan tanah dan cepat hilang dari lapisan tanah karena erosi (Reynolds, 1993). Keadaan ini sangat bertolak belakang dengan phosfat dan ion ammonium yang dapat ditahan dalam waktu yang lama oleh partikel tanah. Pemasukan fosfat diperairan melalui terjadinya proses erosi partikel tanah yang sangat besar. Pertanian, sampah domestik dan industri merupakan sumber utama fosfat dan sering mempengaruhi proses eutofikasi pada perairan.

Perbedaan laju pertumbuhan G.verrucosa pada kedua area, selain disebabkan oleh kerapatan bibit, juga disebabkan oleh faktor ekologis tambak budidaya terutama nutrient di substrat. Hasil penelitian menunjukkan bahwa kandungan kadar nitrat dan fosfat di substrat tambak budidaya mengalami penurunan konsentrasi setiap waktu pengamatan. Dugaan semakin kuat ketika hasil pengukuran kadar nitrat air yang rendah dan fosfat air yang tidak terdeteksi tetapi laju pertumbuhan harian G.verrucosa di area A tetap tinggi.

Menurut Glenn and Doty (1990), selain suhu, tingkat penyinaran, dan derajat pergerakan air yang tinggi, produktivitas rumput laut secara langsung sangat tergantung pada ketersediaan nutrien perairan. Laju penyerapan nutrien rumput laut bervariasi tidak hanya antar spesies tetapi juga antara lokasi dimana rumput laut tersebut hidup (Tomokazu et al., 2004).

\section{SIMPULAN}

Kondisi tambak tidak banyak memberikan pengaruh nyata terhadap laju pertumbuhan rumput laut G.verrucosa. Laju pertumbuhan lebih dipengeruhi oleh faktor penyerapan nutrien dari lingkungan yang dilakukan oleh rumput laut G.verrucosa. Berdasarkan hal tersebut, maka fosfat di substrat tambak budidaya memberikan pengaruh nyata terhadap laju pertumbuhan G.verrucosa.

\section{DAFTAR PUSTAKA}

Alifatri, L. 2012. Laju pertumbuhan dan kandungan agar Gracilaria verrucosa dengan perlakuan bobot bibit terhadap jarak tanam di tambak balai layanan usaha produksi perikanan budidaya Karawang. Jawa Barat. Skripsi. IPB. Bogor.

Andarias, I. 1992. Pengaruh takaran urea dan tsp terhadap produksi bobot kering klekap. Buletin Ilmu Perikanan dan Peternakan.

Anggadiredja, J.T., A. Zatnika., H. Purwoto., dan S. Istini. 2006. Rumput Laut; Pembudidayaan, Pengolahan dan Pemasaran Komoditas Perikanan Potensial. Penebar Swadaya. Jakarta.

Aslan, M. 2006. Budidaya rumput laut. Kanisius. Yogyakarta.

Ask, E.I., and R.V. Asanza. 2002. Advances in cultivation technology of commercial eucheumatoid species: a review with suggestions for future research. Aquaculture 206: 257-277

Bay Of Bengal Programme. (1989). Gracilaria production and utilization in the bay of bengal region. Report of a seminar held in Songkhla. Thailand. $108 \mathrm{pp}$

Brower, J.E., Zar, J.H., and von Ende, C.N. 1990. Field and laboratory methods for general ecology. Third edition. America: Wm.C. Brown Publishers. 
Buschmann, A.H., D. Varela., M. Cifuentes., M.C. Hernandez-Gonzalez., L. Henriquez.,R. Westermeier., and J.A. Correa. 2004. Experimental indoor cultivation of the carrageenophytic red algae Gigartina skottsbergii. Aquaculture 241: 357-370

Chandrkrachang, S., C.J. Chinadit., P.C. Chandayot., and T. Supasiri. 1991. Profitable spin-offs from shrim Seaweed polyculture. Infofish International No. 6: 26-28

Doty, M.S. 1986. Estimating farmer returns from producing Gracilaria and Eucheuma on line farms. Monografias Biological 4: 45-62

Effendi, H. 2003. Telaah kualitas air bagi pengelolaan sumber daya dan lingkungan perairan. Kanisisus. Yogyakarta

Ghomez, K.A., and Ghomez, A.A. 2010. Prosedur statistik untuk penelitian pertanian. Edisi kedua. UIP.Jakarta. $698 \mathrm{hlm}$.

Gordillo, F.J.L., M.J. Dring., and G. Savidge. 2002. Nitrate and phosphate uptake characteristics of three species of brown algae cultured at low salinity. Marine Ecology Progress Series Vol. 234: 111-118

Kadi, A., dan Atmadja, W.S. 1988. Rumput laut jenis algae. reproduksi, produksi, budidaya dan pasca panen. proyek studi potensi sumberdaya alam Indonesia. Jakarta: Pusat penelitian dan Pengembangan Oseanologi. LIPI. $101 \mathrm{hlm}$.

Kamlasi, Y. 2008. Kajian ekologis dan biologi untuk pengembangan budidaya rumput laut (Eucheuma cotonii) Di Kecamatan Kupang Barat Kabupaten Kupang Propinsi Nusa Tenggara Timur. Tesis (tidak dipublikasikan). Sekolah Pascasarjana, Institut Pertanian Bogor. Bogor.

Kartono., M. Izzati2., Sutimin., dan D. Insani. 2008. Analisis model dinamik pertumbuhan biomassa rumput laut gracillaria verrucosa. Jurnal Matematika Vol. 11 No.1: 20-24

Kira, T., H. Ogawa., and N. Sakazaki. 1953. Intraspecic competition among higher plants. I. Competition-yield-density interrelationship in regularly dispersed populations. Journal of the Institute of Polytechnics, Osaka City Uni.ersity 4: 1-16

Martinez, B., and J.M. Rico. 2004. Inorganic nitrogen and phosphorous uptake kinetics in Palmaria palmata (Rhodophyta). Journal of Phycology 40: 642650

Patadjai, R.S. 2007. Pertumbuhan, produksi dan kualitas rumput laut Kappaphycus alvarezii (Doty) Doty pada berbagai habitat budidaya yang berbeda. Disertasi. Program Pascasarjana UNHAS. Makassar.

Shinozaki, K., and Kira, T. 1956. Intraspecic competition among higher plants. VII Logistic theory of the C-D effect. Journal of the Institute of Polytechnics, Osaka City Uni.ersity 12: 69-82

Simanjuntak, M. 2006. Kadar Fosfat, Nitrat dan Silikat kaitannya dengan kesuburan di Perairan Delta Mahakam. Kalimantan Timur. Pusat penelitian oseanografi lembaga ilmu pengetahuan Indonesia. Jakarta.

Tambaru, R., dan F. Samawi. 1996. Beberapa parameter kimia fisika air di muara Sungai Tallo Kota Makassar. TORANI Universitas Hasanuddin. Makassar.

Tomokazu, N., Y. Kosuke., D. Aki., and W. Yoso. 2004. Nitrate and phosphate uptake rates of Sargassum patens and Sargassum siliquastrum. Kyoto Furitsu Kaiyo Senta Kenkyu Hokoku, vol. 26. Japan. Page 21-29. 
Trono, G.C. 1986. Seaweed culture in the Asia-Pacific Region RAPA Publication. Regional Office for Asia and the Pacific. FAO of the United Nations, Bangkok. Thailand. 41 pp.

Wenno, M.R dan J.L. Thenu. 2010. Kajian laju pertumbuhan harian, produksi berat kering dan kandungan karaginan dari eucheuma cottonii pada berbagai bagian thalus, berat bibit dan umur panen. (study of daily growth rate, dry weight produce and carrageenan content from eucheuma cottonii at different part of thallus, seed weight and harvesting time). 56 Ichthyos Volume 9 No 1: 55-59

Weiner, J., and S.C. Thomas. 1986. Size variability and competition in plant monocultures. Oikos 47: 211-222.

Xiang, Y., J. Jiyun., H.E. Ping., L. Ming-zao. 2008. Recent advances on the technologies to increase fertilizer use efficiency. Agricultural Sciences in China Vol.7(4): 469-479 